\title{
PENERAPAN TEKNIK ISOMETRIC ART DAN DIGITAL IMAGING UNTUK STORYTELLING DENGAN DATA VISUALIZATION
}

\author{
Melisa Suardi ${ }^{1)}$, Dinda Djemedi ${ }^{2)}$ \\ ${ }^{1}$ Fakultas Desain Komunikasi Visual, Universitas Putra Indonesia "YPTK” Padang, Jl. Dr Moh. Hatta No 35 \\ Binuang Kp. Dalam, Kp. Periuh Puah Padang \\ email: chanuk2891@gmail.com
}

\begin{abstract}
Abstrak
Perkembangan karya dalam bentuk desain grafis di Indonesia sangat signifikan. Dikarenakan desain grafis sangat efektif dalam mengapresiasikan sekaligus mengekspresikan suatu kegiatan untuk menjadikan suatu rancangan produk yang lebih maksimal. Salah satu bentuk kebutuhan yang mendasar pada desain grafis ialah pada pemaparan data atau biasa dikenal dengan data visual. Pada kawasan Padan Mangateh atau Balai Pembibitan Ternak Unggul (BPTU) Sapi Potong Padang Mengatas daerah Sumatera Barat penyajian data sangat transparan, sehingga bisa di review oleh semua orang. Tapi, penyajian data tersebut masih berupa kolom data. Penelitian ini bertujuan untuk memberikan storytelling data visual yang komunikatif dan informatif menggunakan teknik desain isometric art dan digital imaging. Metode dalam perancangan karya penelitian ini menggunakan tahapan studi desain komunikasi visual, mulai dari pradesain (brief analysis) hingga sampai pada final design. Hasil dalam penelitian ini berupa data visual dari rancangan isometric art dan digital imaging.
\end{abstract}

Keywords: Isometric Art, Digital Imaging, Storytelling, Padang Mangateh

\section{PENDAHULUAN}

Sumatera Barat memiliki kawasan perkembangbiakan sapi dari zaman Belanda. Tempat perkembang biakan sapi ini diresmikan dengan nama Balai Pembibitan Ternak Unggul (BPTU) Sapi Potong Padang Mengatas dengan wilayah kerja meliputi seluruh propinsi di Indonesia. Dalam data terakhir yang bisa dikunjungi pada website resmi (BPTU) Sapi Potong Padang Mengatas ini mencapai 1348 ekor sapi dengan 3 sapi berbeda. Sayangnya data yang diberikan oleh (BPTU) Sapi Potong Padang Mengatas masih biasa tanpa storytelling visual, data ini hanya menjadi sebuah data tanpa pesan. Padahal data bisa dikembangkan dalam bentuk visual sehingga pengunjung website bisa melihat secara perspektif bentuk dan cerita dari data yang di paparkan.

Pengembangan data visual untuk BPTU Sapi Potong Padang Mengatas bisa menggunakan teknik desain isometric art yang digunakan oleh para desainer untuk mengembangkan data kolom menjadi suatu karya bentuk visual yang secara estetika nyaman untuk dilihat.

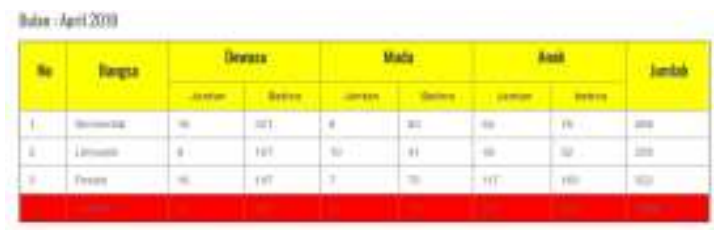

Gambar 1. Data BPTU Sapi Potong Padang Mengatas (Website)

Desain isometric art ialah bentuk teknik baru ang sering dikembangkan dalam penguraian data bentuk desain grafis. Isometric art arti dasarnya ialah visual tiga dimensi dalam layout dua dimensi yang memberikan komposisi secara perspektif, hal ini tentunya membuat data lebih informative untuk pengembangan data visual.

Sedangkan teknik digital imaging membangun gambar menjadi hidup 
dengan menggunakan bentuk photo nyata dari aktifitas gambar. Apabila kedua bentuk ini digabungkan secara teknis makan akan menghasilkan bentuk karya yang inovatif dalam penyajian data.

\section{METODE PENELITIAN}

Metode penelitian teknik desain isometric Art dan digital imaging untuk storytelling with data visualization di Padang Mangatas ini menggunakan tahapan pengumpulan data secara kualitatif. metode penelitian kualitatif adalah suatu riset yang bermaksud untuk memahami fenomena yang dialami oleh subjek penelitian. Misalnya perilaku, persepsi, motivasi, tindakan, dan lain-lain, secara holistic, dan dengan cara deskripsi dalam bentuk kata-kata dan bahasa, pada suatu konteks khusus yang alamiah dan dengan memanfaatkan berbagai metode alamiah.

Pengembangan data visual BPTU Padang Mengatas dengan penerapan isometric art dan digital imaging dilakukan dengan studi desain komunikasi visual. Bentuk studi desain komunikasi visual tersebut meliputi :

1. Elemen desain

2. Prinsip desain

3. Unsur-unsur desain

Dalam perancangan karya elemen desain meliputi:

1. Titik

2. Garis

3. Bentuk

4. Warna

5. Tekstur

6. Dimensi

Prinip desain yang diterapkan dalam perancangan meliputi :

1. Kesatuan

2. Keseimbangan

3. Ritme

4. Keharmonisan
Dasar pengolahan gambar yang dilakukan dengan menggunakan shape, untuk mengetahui bentuk rotasi dan kedalaman yang akan dibuat. Perancangan isometric art di bangun dalam ruang 3 dimensi walaupun hasilnya akan ada pada media 2 dimensi. Berikut contoh isometric art:

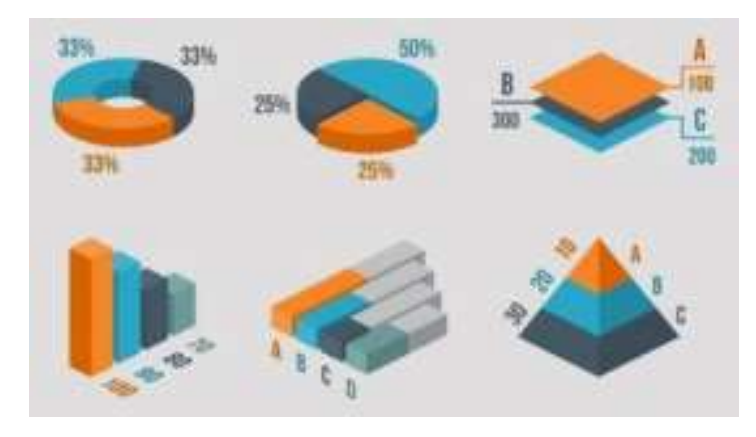

Gambar 2. Isometric art creativemarket.com

\section{HASIL DAN PEMBAHASAN}

Untuk perancangan awal teknik isometric art, maka dilakukan desain bentuk 3 dimensi :

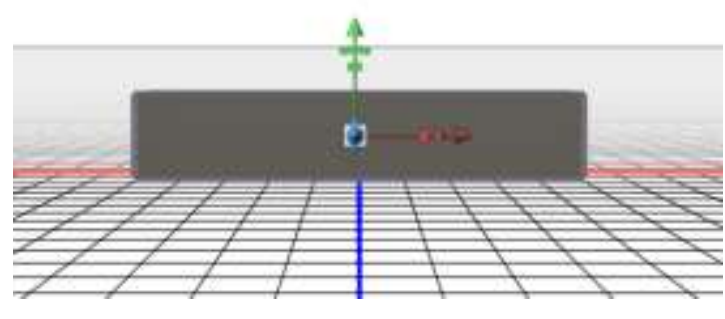

Gambar 3 : Pengolahan bentuk 3 dimensi.

Digital imaging adalah metode untuk melakukan proses pengeditan pada gambar yang sudah di eksekusi. Adapun kriteria dan gambar yang baik untuk dilakukan proses digitalisasikan ialah gambar harus tajam, jelas, punya kontras yang baik, pencahayaan yang bagus (tujuannya untuk 
merekayasa dua image atau lebih menjadi suatu karya kombinasi), yang terakhir harus sesuai konsep.

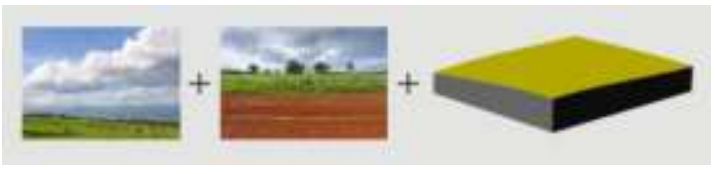

Gambar 4 : Pengolahan digital imaging

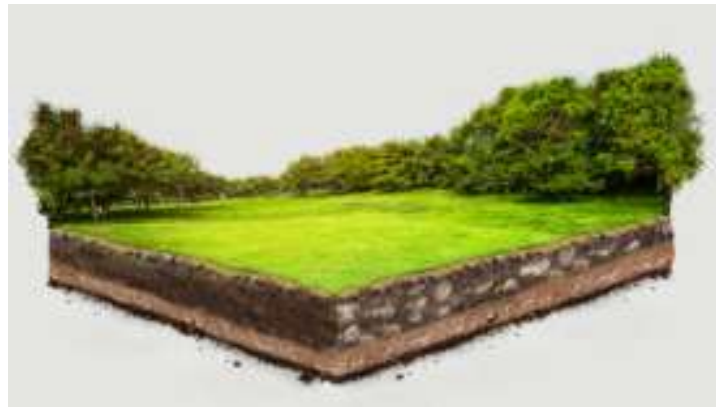

Gambar 5 : Hasil pengolahan bentuk dan telah dilakukan grading warna

Setelah menggabungkan isometric art dan digital imaging menjadi hasil karya kombinasi, maka perlu melakukan input data kedalam desain.

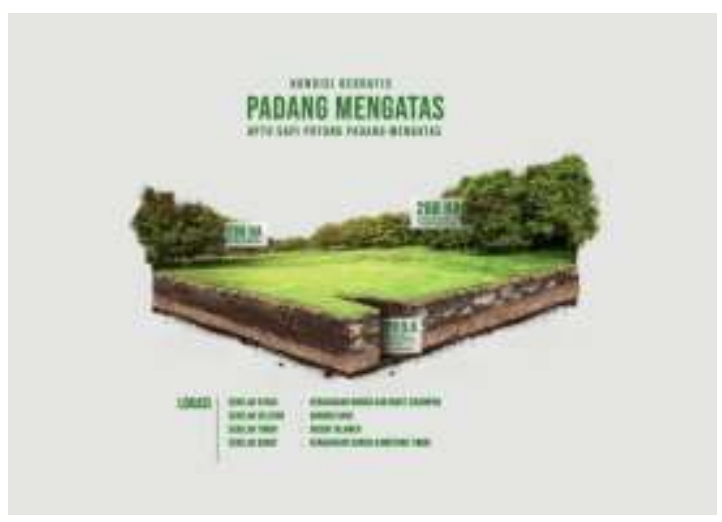

Gambar 6 : Data visual finishing

Berikut beberapa hasil dari pengolahan data visual isometric art dan digital imaging.

\section{POPULASI TERNAK}

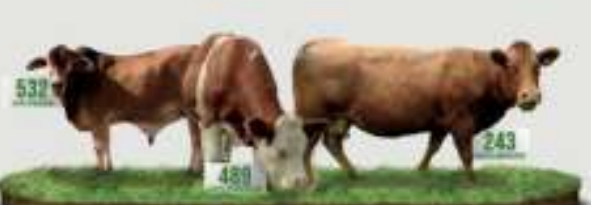

Gambar 7 : Data Sapi BPTU Padang Mengatas

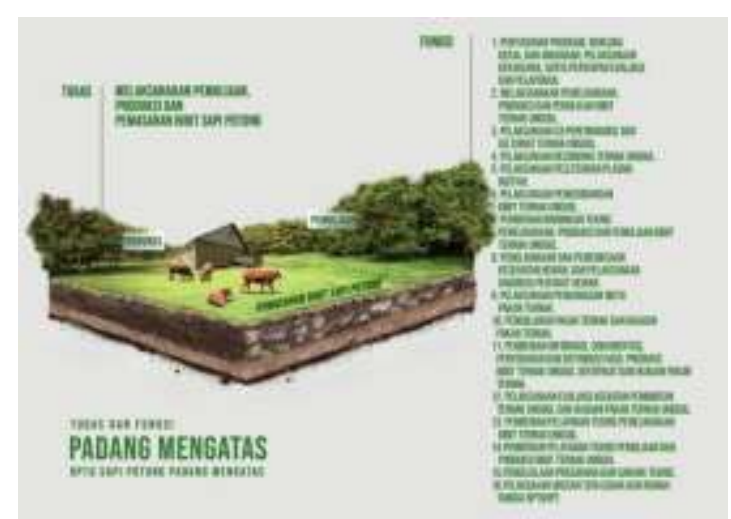

Gambar 8 : Tugas dan Fungsi

Hasil perancangan desain BPTU Sapi Potong Padang Mengatas dalam wujud storytelling data visualization secara estetika selain unsur keindahan juga memudahkan dalam ketersampaian pesan.

\section{SIMPULAN}

Rancangan desain isometric art dan digital imaging dalam pengolahan bentuk visual dari data BPTU Padang Mengatas bisa di alih wahanakan sesuai kebutuhan dalam penyebaran informasi kepada publik.

Desain sebagai unsur estetika dalam mengolah bentuk harus mendukung dalam keterbacaan dan keterfungsian desain kepada public atau target audiens. Karna studi desain komunikasi visual 
menerapkan seni terapan yang tidak hanya pp. 349-354).

karya dimengerti oleh perancang maupun bisa diterima oleh pasar.

\section{UCAPAN TERIMAKASIH}

Dalam merancang penelitian ini tentu ada berbagai pihak yang mendukung atas ketercapaian penelitian ini sebagai kesuksesan Tri dharma perguruan tinggi.

Penulis ingin mengucapkan terima kasih kepada :

1. LLDIKTI Wilayah X.

2. Universitas Putra Indonesia YPTK Padang.

3. LPPM Universitas Putra Indonesia YPTK Padang.

4. BPTU Sapi Potong Padang Mengatas.

5. Fakultas Desain Komunikasi Visual, Universitas Putra Indonesia YPTK Padang.

\section{DAFTAR PUSTAKA}

[1] Nugroho, Sam. 2002. Digital Imaging. IMAGINGPLUS No. 1/2002.

[2] Rustan, Surianto. 2009. Layout. Jakarta : Gramedia Pustaka Utama

[3] Manik, Saut Irianto. 2018. Proses Digital Imaging Iklan Cetak Indonesia. (JSRW) Jurnal Seni Rupa Warna. Jurnal Seni Rupa IKJ.

[4] Moleong, Lexy J. 2005. Metode Penelitian Kualitatif. Bandung : Remaja Rosdakarya

[5] Kusrianto, Adi. 2009. Pengantar Desain Komunikasi Visual. Yogyakarta : Andi

[6] Hadi, A. F., Mulyani, S. R., Ridwan, M., Irzon, I., \& Andini, S. (2020, November). MULTIMEDIA AS A MEDIA FOR ANALYZING STUDENT LEARNING OUT-COMES WITH THE CONCEPT OF BLENDED

LEARNING. In International Conference on Social, Sciences and Information Technology (Vol. 1, No. 1, 